\title{
KETAHANAN HORTIKULTURA DENGAN PEMANFAATAN LUMPUR TINJA DI RT O7 KELURAHAN SAWAH LEBAR BARU KOTA BENGKULU
}

\section{HORTICULTURAL RESISTANCE WITH THE USE OF SLUDGE IN RT 07 SAWAH LEBAR BARU BENGKULU}

\author{
Oleh: \\ Eko Sumartono, Basuki Sigit Priyono, dan Sriyoto \\ Jurusan Sosial Ekonomi Pertanian Fakultas Pertanian \\ Universitas Bengkulu \\ Email:eko_vixion@unib.ac.id
}

\begin{abstract}
Nowadays many limitations in the society of Sawah Lebar Baru inspire further development to use their yards and sludge around them in area. This development program can be used to fulfill the horticulture needs of people in that area which is done by planting vegetables in their own yards in order to increase family income. The output of this development program is to increase housewives' knowledge and skills about the use of sludge as growing medium in the polybags. The socialization and training methods are used in this program. Socialization is done by using personal approach and group approach methods. Training is done to inform about preparation, growing medium filling, and planting vegetables in the polybags. As the effort to maximize the use of yards and increase family income, it is still needed to develop knowledge and skills about the use of sludge as the vegetables growing medium. The role of change agent and communiy services still needed to be increased.
\end{abstract}

Keywords: development, community services, backyard. sludge

\section{PENDAHULUAN}

Pemberdayaan merupakan suatu konsep untuk membrikann tanggung jawab yang lebih besar kepada orang-orang tentang bagaimana menciptakan sesuatu yang bermanfaat di masyarakat. Pemberdayaan akan berhasil jika dilakukan oleh pengusaha, pemimpin, dan kelompok yang dilakukan secara terstruktur dengan membangun budaya yang baik. Konsep pemberdayaan terkait dengan pengertian pembangunan masyarakat dan pembangunan yang bertumpu pada masyarakat.

Program-program pemberdayaan sumber daya manusia telah dilakukan pemerintah. Hal ini sejalan dengan tujuan pembangunan Indonesia yaitu membangun manusia Indonesia seutuhnya, maka pembangunan harus merupakan perubahan sosial yang tidak hanya terjadi pada taraf kehidupan masyarakat belaka tetapi juga pada peranan unsur-unsur di dalamnya. Pembangunan menempatkan manusia sebagai subyek pembangunan. Pemberdayaan masyarakat dalam penanggulangan kemiskinan menjadi komitmen bersama antara pemerintah pusat dengan pemerintah daerah. 
Pada era sekarang ini paradigma pembangunan pertanian harus semakin nyata berorientasi pada manusia, di mana manusia diletakkan sebagai subyek bukan semata-mata sebagai peserta dalam mencapai tujuan nasional. Karena itu pengembangan kapasitas masyarakat guna mempercepat upaya memberdayakan ekonomi masyarakat khususnya perkotaan, merupakan inti dari upaya pembangunan pertanian dalam taraf lingkup perkotaan,. Komoditas yang diutamakan adalah yang bernilai tinggi, mempunyai peluang besar dan mempunyai potensi tinggi serta mempunyai peluang pengembangan.

Pembangunan yang berkelanjtan dan berwawasan lingkungan (suistinable development) merupakan pelestarian ekosistem yang sangat baik. Hutan kota yang paling efektif dalam menanggulangi perubahan suhu terutama di daerah tropis. Bila setiap pekarangan dimanfaatkan secara konseptual, tentu akan terbangun hutan kota (Herlianti, 2014). Dalam mengembangkannya pada sebidang tanah yang khusus diperuntukkan tanaman-tanaman yang dapat digunakan untuk konsumsi. Tanaman ini perlu pengolahan yang baik supaya memberikan hasil yang baik pula, untuk sendiri atau pun dibutuhkan oleh masyarakat untuk dijadikan sebagai obat-obatan (Sajogyo, 1994).

Kecamatan Ratu Agung merupakan salah satu kecamatan yang ada di Kota Bengkulu, terletak di bagian timur dengan luas wilayah 8,92 km persegi. Kecamatan Ratu Agung terdiri dari delapan kelurahan definitif dengan pusat pemerintahan di Kelurahan Nusa Indah. Keadaan topografinya datar dengan ketinggian wilayah berkisar antara 3-18 meter di atas permukaan laut.

Kelurahan Sawah Lebar Baru dahulu merupakan kelurahan pecahan dari Kelurahan Sawah Lebar. Kondisi daerah yang semakin berkembang dan padat memungkinkan kelurahan ini dipecah menjadi dua bagian. Kelurahan Sawah Lebar Baru memiliki 32 RT tersebar dengan lingkup penduduk yang cukup padat, dengan jumlah penduduk 7.292 jiwa. Kegiatan pemberdayaan masyarakat kali ini difokuskan pada kondisi rumah tangga masyarakat RT 07 yang berjumlah 45 kepala keluarga. Secara fisik kondisi areal di RT 07 padat rumah penduduk dengan area lahan bergelombang dan lembah. Masyarakat di RT 07 secara garis besar memiliki kehidupan ekonomi menengah ke bawah. Kehidupan masyarakat di RT 07 Kelurahan Sawah Lebar Baru ini sebagian besar bermata pencarian pengamen, pemulung, pekerja serabutan, pedagang, pegawai swasta, pegawai honorer, dan sebagian kecil pegawai negeri sipil. Akan tetapi pemberdayaan yang dilakukan terhadap kelompok ibu-ibu rumah tangga (PKK RT 07) berjumlah 35 KK di RT 07 Kelurahan Sawah Lebar Baru.

Lingkungan masyarakat yang serba keterbatasan menginsipirasi pembinaan lebih terhadap masyarakat perkotaan ini agar dapat memanfaatan pekarangan rumah dari media lumpur tinja yang berada di lingkungan sekitar Kelurahan Sawah Lebar Baru. Kegiatan pembinaan pemberdayaan masyarakat ini mensiasati kebutuhan masyarakat akan kecukupan hortikultura seperti menanam tanaman sayur-sayuran yang harapannya dapat memenuhi kebutuhan kecil sehari-hari rumah tangga. 
Pemanfaatan pekarangan rumah merupakan salah satu alternatif untuk mewujudkan kemandirian pangan dalam rumah tangga. Pada mulanya bertanam sayur di pekarangan hanya dimaksudkan untuk kebutuhan gizi keluarga dengan memanfaatkan halaman rumah yang tersisa, sehingga kegiatan ini banyak dikembangkan di pedesaan. Dalam pemanfaatan pekarangan menjadi tanaman sayuran sebagai aspek budidaya maka tanaman harus tetap diperhatikan. Usaha di pekarangan jika dikelola secara intensif sesuai dengan potensi pekarangan, disamping dapat memenuhi kebutuhan konsumsi rumah tangga, juga dapat memberikan sumbangan pendapatan bagi keluarga (Herlianti, 2014).

Adapun tujuan dari kegiatan pengabdian kepada masyarakat ini khususnya kelompok arisan ibu rumah tangga di RT 07 Kelurahan Sawah Lebar Baru adalah menumbuhkan kepedulian masyarakat di lingkungan RT 07 terhadapa pemanfaatan lumpur tinja menjadi berdaya guna bercocok tanam sayur-sayuran/hortikultura dengan menggunakan polybag, memberdayakan potensi masyarakat di RT 07 dalam meningkatkan kebutuhan keluarga melalui bercocok tanam sayur-sayuran/hortikultura, dan menciptakan secara optimal pekarangan rumah yang sempit sehingga lebih bernilai dan bermanfaat.

Manfaat dari pembinaan pengabdian kepada masyarakat ini di antaranya membekali masyarakat untuk memiliki kepedulian terhadap lingkungan, memberi alternatif usaha pada masyarakat sehingga dapat meningkatkan kesejahteraan keluarga, dan membekali masyarakat untuk mengoptimalkan pekarangan rumah yang sempit sehingga lebih bernilai.

\section{METODE PENGABDIAN}

Kelompok sasaran kegiatan pengabdian pada masyarakat ini adalah masyarakat khususnya ibu-ibu rumah tangga melalui pemanfaatan lumpur tinja sehingga menghasilkan ketahanan hortikultura. Kegiatan pengabdian ini berlokasi di RT 07 Kelurahan Sawah Lebar Baru, Kota Bengkulu.

Ada dua tahap yang ditawarkan untuk mendukung program ini yaitu:

\section{Persiapan}

Dimana sebelum kegiatan penyuluhan/sosialisasi dilakukan ibu-ibu rumah tangga diminta untuk menceritakan pengetahuan dan pengalaman mereka mengenai pemanfaatan lumpur tinja untuk media tanam hortikultura. Pre-test dan post-test diberlakukan untuk mengetahui tingkat pemahaman ibu-ibu rumah tangga mengenai materi yang akan diberikan. Kemudian Tim Pengabdian akan memberikan kiat-kiat dalam pemanfaatan limbah tinja untuk media tanam hortikultura.

\section{Pelaksanaan}

Metode yang digunakan dalam kegiatan PPM ini adalah metode penyuluhan dan pelatihan. Metode penyuluhan yang dilakukan oleh Tim Pengabdian yaitu dengan metode pendekatan personal dan pendekatan kelompok (Purwoko, 2009). Penyelenggaraan 
pelatihan dilakukan untuk pembuatan, pengisian media tanam, dan penanaman hortikultura (sayuran) di polybag dan pembagiannya.

\section{HASIL DAN PEMBAHASAN}

\section{Proses pencapaian hasil}

Koordinasi dan partisipasi mitra penerima dapat dirinci sebagai berikut:

a. Koordinasi antara tim pelaksana dengan mitra penerima warga/ibu-ibu PKK di RT 07 terkait dengan jadwal pelaksanaan kegiatan penyuluhan, pembagian benih, bibit dan bahan media lumpur tinja serta pelatihan.

b. Berkoordinasi dengan Instalasi Pengolahan Lumpur Tinja (IPLT) Kelurahan Sawah Lebar Baru.

c. Berkoordinasi dengan Ketua RT 07 RW 02 Kelurahan Sawah Lebar Baru dan ketua serta beberapa anggota ibu-ibu PKK RT 07 Kelurahan Sawah Lebar Baru.

d. Membantu menyediakan konsumsi (memesan dan menyiapkan).

e. Memperkenalkan tim pelaksana kepada beberapa anggota ibu PKK.

Secara umum tergambarkan kepuasan mitra penerima benih, bibit dan bahan media lumpur tinja dapat dilihat sebagai berikut:

a. Beberapa peserta antusian menanyakan dan berdiskusi serta masih menghendaki diskusi tambahan terkait dengan program pembinaan yang disampaikan meskipun jadwal penyuluhan sudah usai.

b. Peserta minta segera setelah penyuluhan awal, cepat terealisasi dan sudah tidak sabar menerima bantuan benih, bibit, dan bahan media lumpur yinja disertai pelatihan.

c. Beberapa ibu-ibu PKK meminta tambahan benih, bibit, dan bahan media lumpur tinja harapannya mereka bisa menanam lebih dari yang ditargetkan.

d. Peserta meminta jadwal penyuluhan dimulai setelah jam 15.30 WIB di hari Minggu dengan harapan pada saat penyuluhan semua dapat hadir.

Aspek manajemen:

a. Meskipun ibu-ibu PKK penerima benih, bibit, dan bahan media lumpur tinja ada beberapa orang sudah pernah menanam di dalam polybag, namun secara keseluruhan kondisi ketidaktahuan dan minimnya informasi pemanfaatan lumpur tinja masih sangat kurang sehingga perlu diintensifkan.

b. Manajemen penanaman tanaman hortikultura sangat tergantung pada perawatan, perawatan tanaman yang tidak baik akan menimbulkan kondisi tanaman yang kurang sehat dan berakibat pada hasil yang dicapai tidak maksimal.

Tim pengabdian sudah melakukan koordinasi di lapangan ke lokasi PPM Pembinaan di RT 07 Kelurahan Sawah Lebar Baru pada tanggal 8 Mei 2016. Tinjauan lapangan ini bertujuan untuk memastikan secara spesifik target audien yang akan dilibatkan dan secara khusus menghasilkan: 
a. Nama-nama mitra penerima benih, bibit, dan bahan media lumpur tinja yang potensial untuk terlibat dalam PPM Pembinaan Universitas Bengkulu.

b. Jenis-jenis benih dan bibit yang bisa ditanam di pekarangan rumah sehingga dapat membantu ketahanan hortikultura keluarga.

c. Detail permasalahan yang sering muncul di lapangan, yang utamanya adalah rendahnya pengetahuan warga tentang manfaat menanam di pekarangan dan manfaat menggunakan media lumpur tinja bagi tanaman.

d. Penjadwalan (waktu, tempat, dan siapa yang diundang) acara penyuluhan tentang sosialisasi mengenai pengenalan dan manfaat lumpur tinja apabila digunakan sebagai media tanam hortikultura mendapat hasil yang tidak kalah baiknya dengan media lainnya. Penyuluhan telah dilakukan pada tanggal 22 Mei 2016.

e. Mengetahui adanya kegiatan PPM Pembinaan yang dilakukan, maka anggota RT 05 dan RT 06 juga menyatakan tertarik untuk ikut dalam daftar penerima benih, bibit, dan bahan media lumpur tinja. Namun karena program PPM Pembinaan ini terbatas, maka tim memberikan keleluasaan jika mau ikut penyuluhan dan dibatasi, serta akan memberikan kesempatan selanjutnya jika ada hal yang sama akan diajukan pada PPM Pembinaan tahun 2017.

\section{Sosialisasi awal pengenalan manfaat menanam hortikultura di pekarangan rumah dan lumpur tinja sebagai media}

Penyuluhan awal pengenalan manfaat menanam hortikultura di pekarangan rumah dan lumpur tinja sebagai medianya dilaksanakan pada tanggal 22 Mei 2016, disampaikan materi terkait dengan media dan menanam hortikultura yaitu:

a. Manfaat menanam hortikultura di pekarangan rumah

b. Kelebihan dan kekurangan media pupuk dari lumpur tinja

c. Cara menanam vertikultur dan manajemen perawatannya

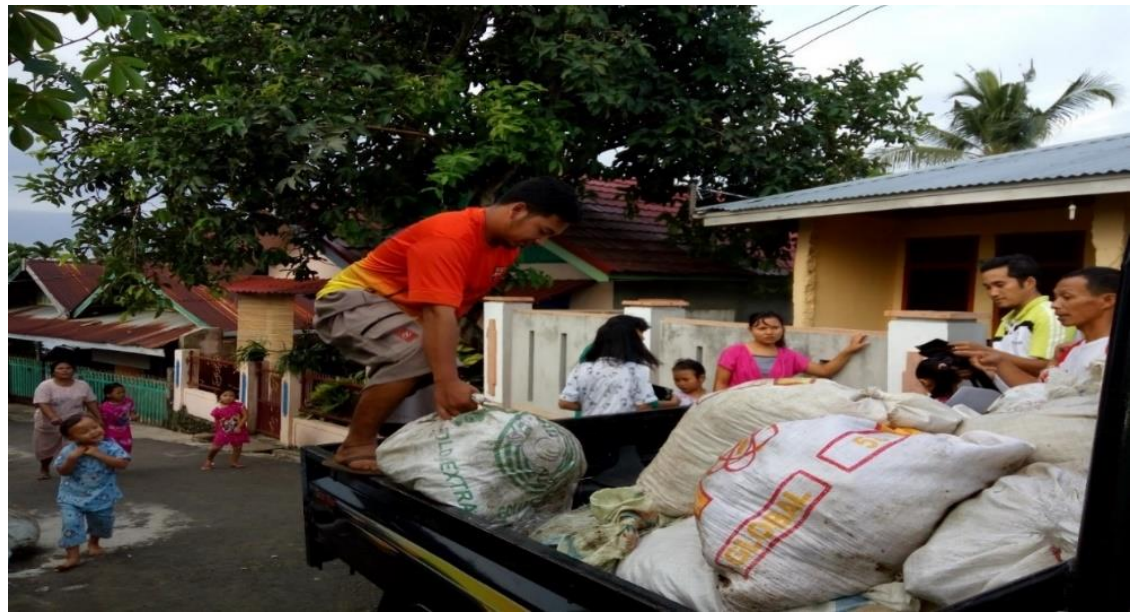

Gambar 1. Proses Pengangkutan Pupuk Lumpur Tinja di Sawah Lebar Baru 
Dalam kegiatan penyuluhan awal pengenalan manfaat menanam hortikultura di pekarangan rumah dan lumpur tinja sebagai media yang hadir sangat antusia menanyakan beberapa pertanyaan yang sangat relevan dengan kehidupan sehari-hari mereka dan yang mereka temui di lapangan, seperti jenis tanaman yang dapat ditanam, cara mencegah penyakit tanaman, cara perawatan agar tanaman tumbuh dengan baik, dan lain-lain.

Acara penyuluhan ini disampaikan juga beberapa jenis racun pestisida, tanaman inang sekitar rumah yang dapat menjadi bahan tumbuh kembangnya penyakit dan virus bercak pada cabe dan terong, serta untuk tumbuh kembangnya tanaman dan bagaimana proses pengolahannya antara lain tanaman menggunakan racun berbahan Acephate, Bifenthrin, Cyfluthrin, Deltamethrin, Lamda-cyhalothrin Permethrin, dan merk Bestox lainnya. Karena racun standar tersebut sangat mahal harganya, hingga Rp 100.000,00.

Mitra penerima disarankan untuk mencoba beberapa jenis racun tradisional dan pengelolaan tanaman inang di sekitar rumah antara lain dengan penyemprotan air kencing sapi yang didiamkan selama dua minggu dengan perbandingan 1:6 dan dapat dicampur dengan daun tembakau, kunyit, dan neem atau imba (Azadirachta indica). Percepatan pertumbuhan tunas dan akar bisa dengan menggunakan rendaman air dicampur bawang merah dan sedikit bawang putih dan cucian beras.

Setelah kegiatan penyuluhan berlangsung, tim memulai menghitung dan merincikan pembelanjaan yang akan diberikan kepada mitra penerima benih, bibit, dan bahan media lumpur tinja. Adapun rincian benih, bibit, dan bahan media lumpur tinja yang dilakukan tim pelaksana PPM Pembinaan Ketahanan Hortikultura dengan pemanfaatan lumpur tinja di RT 07 Kelurahan Sawah Lebar Baru adalah:

a. Pembelian polybag untuk 36 orang penerima benih, bibit, dan bahan media lumpur tinja pada tangggal 25 Mei 2016.

b. Pemesanan bibit seledri pada awal bulan Juni 2016 dan diambil pada tanggal 19 Juni 2016.

c. Pembelian benih dilakukan pada tanggal 17 Juni 2016 untuk beinh kacang panjang saja dikarenakan stok benih lain untuk jenis terong, kangkung, dan cabe tidak sesuai dengan kualitas yang dikehendaki.

d. Pembelian benih selanjutnya pada tanggal 19 Juni 2016 dengan beberapa pilihan seperti cabe, terong, kangkung, kekurangan benih kacang panjang dan bibit selederi.

\section{Proses pengangkutan pupuk lumpur tinja dan pembagian benih, bibit tanaman}

Pada tanggal 20 Juni 2016 kerja sama dengan pengelola IPLT Kelurahan Sawah Lebar Baru, maka telah terkumpul 70 karung sudah diisi dan dibayarkan langsung biaya pengisian kepada bapak Parman. Proses pengangkutan dilakukan dua kali dikarenakan terkendala akomodasi yang tidak dapat menampung jumlah kelebihan muatan dalam membawa pupuk lumpur tinja tersebut. Pada tanggal 29 Juni 2016 pelunasan transport angkut dan tenaga kerja angkut serta pembagian pupuk lumpur tinja. 
Selanjutnya pembagian benih dan bibit sayur- sayuran seperti benih kangkung, kacang panjang, cabe, terong, sledri dan daun bawang kepada ibu- ibu PKK di RT 07 Kelurahan Sawah Lebar Baru sejumlah 4-5 polibag.

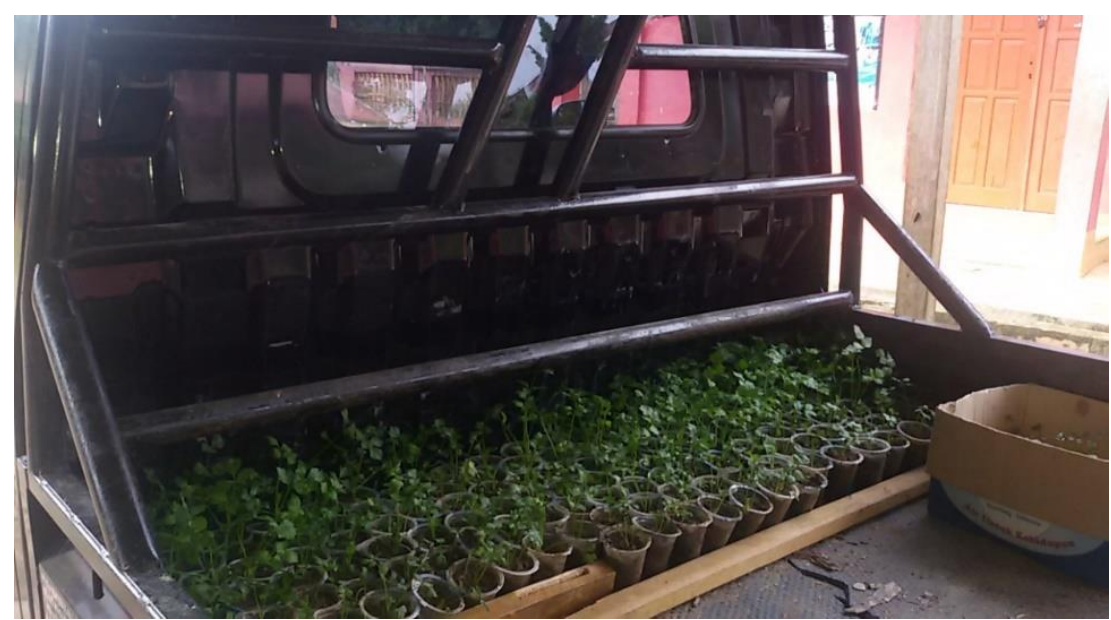

Gambar 2. Benih dan bibit sayur- sayuran

\section{Pelatihan proses penanaman dan praktik lapangan manajemen perawatan}

Pada tanggal 26 Juni 2016 kegiatan pelatihan proses penanaman dan praktik lapangan manajemen perawatan dilaksanakan namun ada beebrapa kendala yang terjadi:

a. Pelaksanaan pelatihan proses penanaman dan praktik lapangan manajemen perawatan dilaksanakan di depan rumah Bapak RT 07 yang relatif sempit sehingga ada beberapa ibu-ibu dibantu bapak-bapak melakukannya di pinggir jalan gang RT 07 Jambu 3.

b. Sebagian ibu-ibu sudah duluan mengisi tanah ke dalam polybag sehingga proses dan tata cara saat pelatihan sebagian besar diikuti oleh beberapa ibu-ibu yang memang belum melakukan pengisian ke dalam polybag. Namun ada beberapa ibu-ibu yang sudah terlanjur mengisi ikut ke dalam proses pelatihan penanaman.

c. Pengetahuan yang minimal mengenai perawatan penanaman.

d. Pelaksanaan yang cukup singkat berlangsung karena terkendala hujan saat praktik manajemen perawatan. 


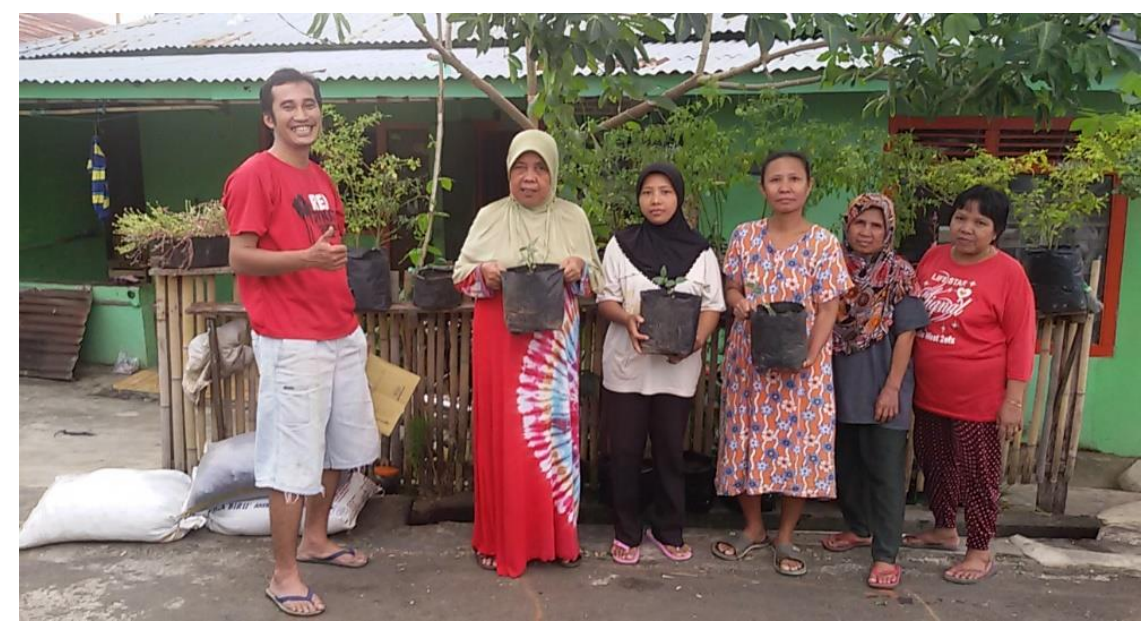

Gambar 3. Benih dan bibit sayur- sayuran yang dibagikan kepada Ibu- Ibu PKK di Kelurahan Sawah Lebar Baru

Kegiatan praktik manajemen perawatan terfokus pada perawatan mulai perkecambahan menjadi bibit, pemeliharaan dan menjelang panen. Perawatan pada proses perkecambahan harus menjaga kelembapan dan sinar matahari yang cukup. Pengaturan ini agar proses perkecambahan berlangsung dengan baik. Siraman pagi-siang sampai sore selama 10 hari benih berkecambah. Setelah benih berkeccambah selama 10 hari kegiatan penyiraman dikurangi pagi dan sore. Selanjutnya pada hari ke 21 penyiraman dilakukan sore hari saja sampai siap pindah setelah bibit berumur lebih dari 30 hari.

Kegiatan selanjutnya perawatan saat pemeliharaan dilakukan setelah bibit dipindah per polybag 1 bibit yang sudah dipilih dan siap ditanam. Pemeliharaan dilakukan setiap 2 hari sekali dilakukan penyiraman dan diletakkan di sinar matahari yang cukup selama tanaman mulai berbunga dan berbuah. Sebaiknya setiap sekali siram dilakukan penyiraman menggunakan air bilasan dari beras dan seminggu sekali dicampur dengan gilingan bawangmerah agar perakaran dan perkembangan tanaman semakin cepat besar. Penyemprotan dilakukan seminggu sekali dengan menggunakan larutan bawang merah dicampur daun nimba atau pestisida nabati lainnya. Hampir selama pemeliharaan ibu-ibu tidak mencampur pupuk kimia. Sehingga menghasilkan tanaman organik.

Menjelang panen sebaiknya rutin melakukan penambahan pupuk lumpur tinja organik yang baru sehingga nutrisi tidak akan berkurang dan penambahan penyiraman dengan menggunakan siraman air perasan beras dan larutan bawang merah. Agar hasil panen maksimal sebaiknya dilakukan penyiraman 2 kali sehari selama pembuahan. Lakukan penyemprotan dengan menggunakan pestisida nabati agar tanaman lebiih baik dan hindari menggunakan pestisida berbahan kimiawi. 


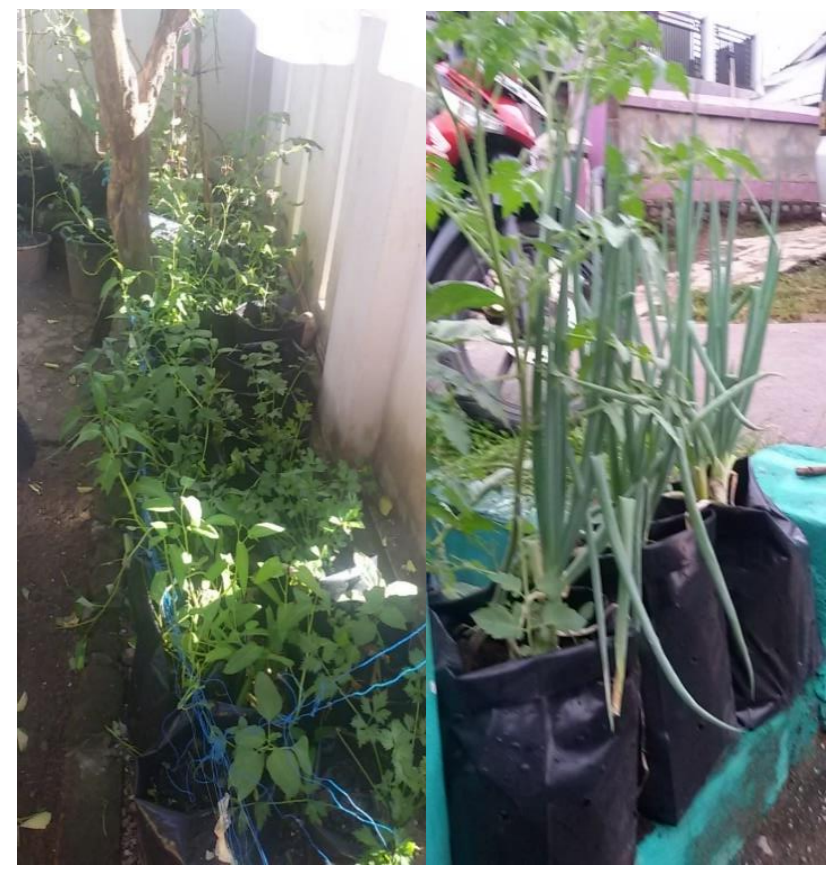

Gambar 4. Sayur- sayuran setelah berumur 4 (empat) minggu, siap dipanen

\section{KESIMPULAN DAN SARAN}

Secara keseluruhan dapat disimpulkan sampai saat ini bahwa kegiatan PPM Pembinaan dapat:

a. Meningkatkan pengetahuan masyarakat dalam bidang pertanian, terutama pada masalah pemanfaatan lumpur tinja sebagai media tanaman hortikultura, pemanfaatan pekarangan rumah, dan manajemen perawatannya.

b. Tumbuhnya kepedulian masyarakat khususnya kelompok arisan ibu-ibu PKK di lingkungan RT 07 terhadap pemanfaatan lumpur tinja menjadi berdaya guna bercocok tanam dengan menggunakan polybag.

c. Mitra penerima dalam hal ini ibu-ibu PKK berkeinginan kuat untuk dapat segera mengaplikasikannya serta mengimplementasikannya dari kegiatan yang sudah dilakukan.

d. Ibu-ibu PKK dan warga bapak-bapak sangat antusias dan menyambut baik adanya PPM Pembinaan. Terciptanya pemanfaatan secara optimal pekaraangan rumah yang sempit sehingga lebih bernilai dan bermanfaat.

Anggota ibu-ibu PKK disarankan agar terus semangat memanfaatkan pekarangan rumah dengan menanam tanaman hortikultura dan ditingkatkan lagi secara terus-menerus menanam tanaman sehingga dapat meringankan beban ekonomi keluarga serta dapat memanfaatkan media sekeliling lingkungan sebagai media lain tanpa harus tergantung pada pupuk kandang dari kotoran ternak. Dalam upaya mensukseskan program 
pemanfaatan pekarangan ini, peran penyuluh dan penyuluhan pertanian di lokasi pengabdian juga perlu ditingkatkan.

\section{DAFTAR PUSTAKA}

Herlianti, Rika, 2014, Dampak Pemanfaatan Pekarangan dengan Tanaman Sayuran terhadap Pengeluaran Pangan Rumah Tangga (Studi Kasus di Desa Bukit Peninjauan I Kecamatan Sukaraja Kabupaten Seluma), Jurusan Sosial Ekonomi Pertanian Fakultas Pertanian Universitas Bengkulu, Skripsi, Tidak dipublikasikan.

Purwoko, Agus, 2009, Dasar-dasar Penyuluhan Pertanian, Badan Penerbit Fakultas Pertanian, Universitas Bengkulu.

Sajogyo, 1994, Menuju Gizi Baik yang Merata di Pedesaan dan di Kota, Gajah Mada Press, Yogyakarta. 